\title{
Kecanduan Media Sosial (FoMO) Pada Generasi Milenial
}

\author{
Lira Aisafitri ${ }^{1}$, Kiayati Yusriyah ${ }^{2}$ \\ Fakultas Ilmu Komunikasi Universitas Gunadarma \\ Email: liraaisafitri@gmail.com
}

Received: November 27, 2020; Revised: February 20, 2021; Accepted: February 26, 2021

\begin{abstract}
Abstrak
Penelitian ini membahas mengenai "Kecanduan Media Sosial (FoMO) Pada Generasi Milenial", dimana Generasi Milenial paling aktif menggunakan media sosial sehingga mempengaruhi gaya hidup mereka. Penelitian ini bertujuan untuk mengetahui dampak dari kecanduan media sosial atau disebut dengan sindrom FoMO (Fear of Missing Out) pada generasi milenial di kota Depok. Teori yang digunakan teori Determinasi Diri untuk melihat dampak seperti apa saja yang timbul pada diri Generasi Milenial yang mengalami kecanduan media sosial (FoMO). Penelitian ini menggunakan jenis penelitian kualitatif dengan pendekatan fenomenologi, dimana teknik pengumpulan data yang digunakan adalah observasi, wawancara, dan dokumentasi. Hasil penelitian menemukan bahwa Milenial yang mengalami kecanduan media sosial (FoMO) memiliki dampak positif dan negatif pada kehidupan sehari-hari mereka, dimana dengan kecanduan media sosial menjadikan diri mereka selalu terupgrade dengan informasi-informasi terbaru yang secara tidak langsung membuat diri mereka memiliki motivasi untuk melakukan suatu hal.
\end{abstract}

Kata Kunci: Fear of Missing Out; Fenomenologi; Kecanduan Media Sosial; Milenial; Sindrom FoMO.

\begin{abstract}
This research discusses "Social Media Addiction (FoMO) in Millennial Generation, where Millennial Generation is most actively using social media so that it affects their lifestyle. This study aims to determine the impact of social media addiction or the socalled FoMO (Fear of Missing Out) syndrome on the millennial generation in Depok. The theory used by the Self-Determination theory is to see what kind of impacts arise on Millennials who experience social media addiction (FoMO). This research uses qualitative research with a phenomenological approach, where the data collection techniques used are observation, interviews, and documentation. The results of the study found that millennial of social media addiction (FoMO) have a positive and negative impact on their daily lives, in which social media addiction allows themselves to be constantly uplifted with new information that indirectly gives themselves the motivation to do something.
\end{abstract}

Keywords: Fear of Missing Out; Phenomenology; Social Media Addiction; Millennial; FoMO Syndrome. 


\section{Pendahuluan}

Kecanduan media sosial merupakan suatu gangguan perilaku dalam penggunaan media sosial

Media sosial atau dikenal sebagai situs jejaring sosial, memudahkan pengguna dalam berinteraksi dengan orang lain sehingga dapat membentuk ikatan sosial secara virtual, selain itu juga dapat mempresentasikan dirinya secara berlebihan dan mengarah kepada kecenderungan untuk terus menerus menggunakan media sosial (Eijnden, dkk., 2016).

melalui media sosial. Selain itu, lamanya seseorang mengakses media sosial merupakan salah satu faktor yang menjadi pemicu FoMO. Seperti yang dapat kita lihat data survei laman Hootsuite We Are Social pada gambar 1.1.

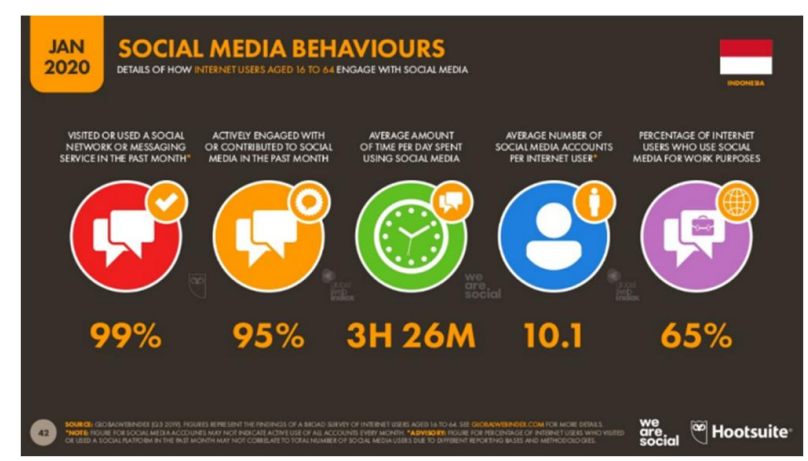

Gambar 1.1 Social Media Behaviours

Sumber: https://datareportal.com/reports/digital-2020-indonesia

Pada gambar 1.1 berdasarkan data survei laman Hootsuite We Are Social terlihat bahwa rata-rata masyarakat di Indonesia setiap hari menghabiskan waktu selama 3 jam 26 menit dalam mengakses media sosial. Hal ini menyebabkan situs media sosial telah menjadi faktor yang berkontribusi besar terhadap sensasi FoMO yang menjadi gaya hidup Milenial.

Gaya hidup menggambarkan "keseluruhan diri seseorang" dalam berinteraksi dengan lingkungannya. Gaya hidup dapat dipahami mengenai tentang bagaimana orang menghabiskan waktunya atau disebut aktivitas, apa yang penting orang pertimbangkan pada lingkungannya (minat), dan apa yang orang pikirkan tentang diri sendiri dan dunia

di

sekitar atau opini. Gaya hidup dipengaruhi oleh keterlibatan seseorang dalam kelompok sosial, dari seringnya berinteraksi dan menanggapi berbagai stimulus.

Menurut Przybylski,et.al (dalam Dossey, 2014) menemukan beberapa fakta mengenai FoMO diantaranya adalah FoMO merupakan kekuatan pendorong dibalik penggunaan internet dan media sosial khususnya, tingkat FoMO tertinggi dialami oleh remaja dan dewasa awal (emerging adulthood), rendahnya kepuasaan dalam hidup dapat mendorong FoMO yang tinggi dan FoMO yang tinggi disebabkan karena terlalu sering mengakses internet ketika sedang menjalani aktivitas yang 
membutuhkan konsentrasi tinggi seperti mengemudi maupun sedang belajar didalam kelas. Seperti yang

dapat kita lihat data survei laman Hootsuite We Are Social pada gambar 1.2.

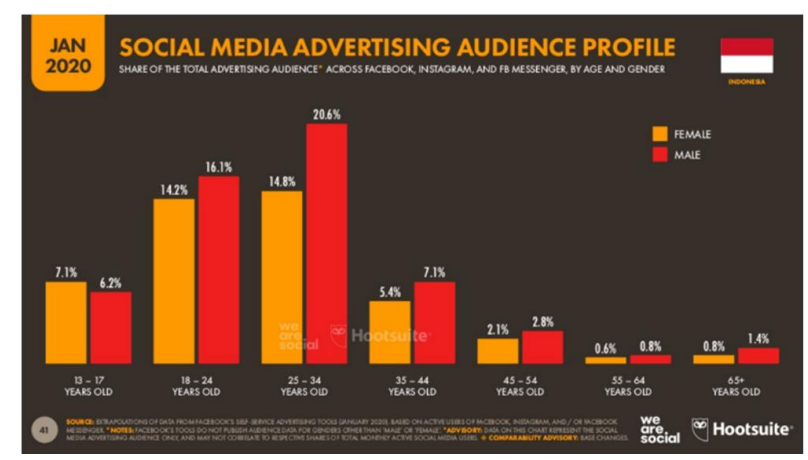

Gambar 1.2 Social Media Advertising Audience Profile Sumber: https:/ / datareportal.com/ reports/ digital-2020-indonesia

Pada gambar 1.2. dapat dilihat banyaknya pengguna media sosial di Indonesia berdasarkan data survei laman Hootsuite We Are Social. Pengguna media sosial di Indonesia paling banyak pada rentang usia 1834 tahun, dimana pada usia $18-24$ tahun jumlah pria mencapai $16.1 \%$ dan lebih unggul daripada pengguna wanita dengan persentase $14.2 \%$. Sementara pada rentang usia 25-34 tahun, persentase pengguna pria mencapai $20.6 \%$, dimana memiliki persentase lebih besar dibandingkan pengguna wanita dengan persentase $14.8 \%$.

Rentang usia 18-34 tahun merupakan generasi milenial yang tidak bisa berlama-lama tanpa menggunakan media sosial, karena generasi milenial merupakan penduduk terbesar dengan usia produktif, dimana salah satu ciri utama generasi milenial ditandai oleh peningkatan penggunaan dan keakraban dengan komunikasi, media, dan teknologi digital.
Seperti halnya, mulai dari bangun tidur sampai tidur lagi, orang berbondong-bondong menyajikan atau berusaha menjadi yang pertama untuk update informasi tertentu. Sedangkan orang yang mengalami FoMO adalah orang yang paling gampang merasa cemas, dan akan terus menerus kepikiran jika mereka tahu bahwa mereka melewatkan sebuah berita yang sedang happening.

Ketergantungan seseorang terhadap teknologi, terutama media sosial turut mengubah bagaimana media sosial digunakan. Generasi milenial saat ini tidak hanya menghabiskan waktu untuk mencari tahu berita yang mereka butuhkan, namun tanpa sadar mereka menggunakannya untuk mengikuti kehidupan dan kegiatan orang lain, dimana seolah-olah mereka harus mengetahui setiap hal yang dilakukan oleh orang-orang terdekatnya karena media sosial memudahkan individu untuk terus up to date terhadap semua berita baru, apa saja yang telah 
mereka lewatkan dan memastikan bahwa mereka tidak tertinggal. Bahkan aktivitas ketergantungan pada media sosial ini menimbulkan kegelisahan pada diri mereka sendiri. Seperti yang dapat kita lihat data survei laman Hootsuite We Are Social pada gambar 1.3.

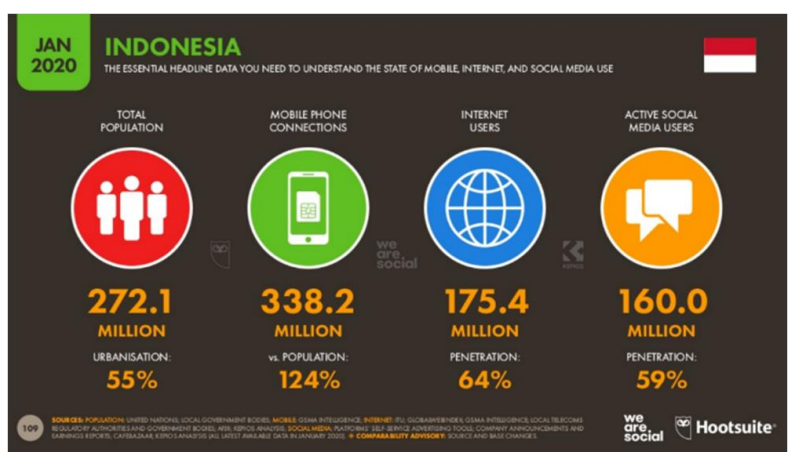

Gambar 1.3 Indonesia

Sumber: https:/ / datareportal.com/ reports/ digital-2020-indonesia

Pada gambar 1.3. berdasarkan laman Hootsuite We Are Social, dapat dilihat tedapat 272,1 juta penduduk di Indonesia, dimana menunjukkan bahwa pengguna media sosial memiliki 160 juta Pengguna, yang berarti setengah dari jumlah penduduk Indonesia merupakan pengguna media sosial. Penggunaan media dapat di ilustrasikan ketika seseorang memilih dan menggunakan suatu media didasari oleh adanya motif tertentu untuk menggunakan media. Setiap orang memiliki motif yang berbeda dalam menentukan media yang akan digunakan. Ketika motif tersebut terpenuhi maka akan terlihat bagaimana orang tersebut menggunakan media yang telah dipilihnya untuk memenuhi kebutuhannya. Kebiasaan seseorang untuk memenuhi kebutuhannya dapat terlihat dari frekuensi, durasi, situasi dan kondisi, waktu dan tempat, pilihan isi media, dan pilihan aplikasinya (Syahreza dan Tanjung, 2018).
Perkembangan Teknologi Informasi dan Komunikasi (TIK) dapat memudahkan bagi penggunanya untuk terhubung dengan media sosial. Berdasarkan laporan Asosiasi Penyedia Jasa Internet Indonesia (APJII), pengguna internet tertinggi di pulau Jawa pada tahun 2018 khususnya Provinsi Jawa Barat mencapai $16,7 \%$ (APJII, 2018).

Kota Depok yang merupakan salah satu kota di Provinsi Jawa Barat mendapatkan penghargaan dari TeSCA, yang merupakan sebuah program pemberian yang diberikan oleh PT Telekomunikasi Indonesia, Tbk yang bertujuan untuk mengukur pemanfaatan Teknologi Informasi dan Komunikasi (TIK) perguruan tinggi di Indonesia, dan merupakan hal penting bagi perguruan tinggi karena hal tersebut menyangkut pengakuan atas reputasi dan kualitas pembelajaran di kampus tersebut.

TeSCA memberikan penghargaan kepada Perguruan Tinggi Universitas Indonesia yang 
menduduki peringkat ke 2 TeSCA, dan Universitas Gunadarma menduduki peringkat ke 3 TeSCA berdasarkan laman (https://ayokuliah.id/, diakses pada 13 Maret 2020 pukul 16.28 WIB). Jika dikaitkan dengan fenomena FoMO, maka generasi milenial yang berstatus mahasiswa di Kota Depok termasuk ke dalam generasi yang melek akan teknologi, dan dapat diasumsikan hal tersebut sudah masuk ke dalam kategori FoMO. Hal ini dikarenakan menurut Przybylski, et,al (dalam Dossey, 2014), kekuatan pendorong dibalik penggunaan internet atau media sosial adalah FoMO dengan tingkat tertinggi dialami oleh remaja dan dewasa awal seperti mahasiswa. Mahasiswa yang berusia 18-25 tahun adalah kelompok yang terlihat lebih rentan terhadap ketergantungan pada internet dan media sosial.

Selain itu media sosial juga dapat memberikan dampak negatif kepada penggunanya seperti adanya rasa kegelisahan pada diri mereka ketika mereka mengecek media sosialnya dan melihat berbagai keseruan yang sedang dilakukan oleh teman-teman mereka, sehingga mereka tidak bisa untuk berhenti memantau aktivitas orang lain di media sosial. Hal itu dapat menyebabkan ketergantungan yang cenderung akan menjadi suatu kebutuhan bagi penggunanya untuk terus mengikuti apa yang sedang terjadi di luar sana, dan hal tersebut merupakan salah satu ciri dari fenomena FoMO.

Berdasarkan penjelasan diatas maka peneliti tertarik untuk melakukan penelitian studi fenomenologi mengenai fenomena
FoMO pada generasi milenial di kota Depok khususnya mahasiswa Universitas Indonesia dan mahasiswa Universitas Gunadarma yang mendapatkan penghargaan dari TeSCA.

\section{Kerangka Teori}

Fenomena kekhawatiran karena tidak up to date terhadap apa yang terjadi dikenal dengan istilah Fear of Missing Out atau disingkat dengan istilah FoMO. Fenomena sindrom FoMO merupakan salah satu fenomena komunikasi intrapersonal dimana seseorang merasakan kekhawatiran, kecemasan, hingga ketakutan jika ketertinggalan informasi yang beredar di media sosial.

Kondisi gejala FoMO ini semakin kuat menyerang, dimana media sosial mengambil alih kehidupan nyata dan menjadikan media sosial sebagai bagian kehidupan sehari-hari yang sangat penting. Penggunaan media sosial sebagai sarana komunikasi dapat diakses melalui smartphone yang pengguna bisa akses kapanpun dan dimanapun.

Kaitan FoMO dengan kecanduan media sosial dapat dilihat dari peran media sosial terhadap individu yang mengalami FoMO. Kebutuhan dan dorongan yang muncul akibat FoMO dalam mempertahankan komunikasi dapat terpenuhi melalui media sosial. Tersedianya informasi dari media sosial memungkinkan individu untuk mengetahui peristiwa apa saja yang dilakukan orang lain sepanjang waktu. Hal tersebut menyebabkan individu yang mengalami FoMO 
dapat mengarah kepada kecanduan media sosial (Abel, 2016).

Besarnya kebutuhan psikologis yang dijelaskan pada teori determinasi diri (Self Determination Theory) dimana terdapat tiga kebutuhan psikologis utama manusia diantaranya, competence, autonomy, dan relatedness. Ryan et al (2008) menyatakan bahwa kepuasan atas tiga kebutuhan psikologis dasar terdapat didalam teori determinasi diri yang mampu meningkatkan kesehatan mental seseorang seperti mengurangi depresi, kekhawatiran, dan kualitas hidup yang lebih tinggi.

$$
\text { Menurut Abel (2016) }
$$

seseorang dapat dikatakan FoMO apabila ia mengalami gejala-gejala seperti tidak dapat melepaskan diri dari ponsel, cemas dan gelisah jika belum mengecek akun media sosial, lebih mementingkan berkomunikasi dengan rekan-rekannya di media sosial, terobsesi dengan status dan postingan orang lain, dan selalu ingin eksis dengan men-share setiap kegiatannya dan merasa depresi jika sedikit orang yang melihat akunnya. Hal tersebut sesuai dengan semua pernyataan subjek yang diteliti bahwa mereka merasa tidak dapat lepas dari smartphone miliknya, selalu mengecek media sosial, selalu memposting mengenai apapun, seperti kegiatan, hal-hal yang disukai, perasaan yang sedang dirasakan, dan moment yang dianggap berharga dan tidak boleh dilewatkan.

Determinasi adalah sikap mental yang ditandai dengan komitmen yang kuat untuk mencapai tujuan tertentu meskipun terdapat hambatan dan kesulitan; suatu proses dalam pembuatan keputusan, mencapai kesimpulan, atau memastikan hasil akhir dari setiap proses (Vandenbos, 2008).

Menurut Rogers (dalam Semium, 2006) self adalah pembawaan sejak lahir dan adanya konsistensi dan persepsi tentang karakteristik-karakteristik "saya" atau "aku" dan persepsi tentang hubungan-hubungan "saya" atau "aku" dengan orang lain. Determinasi diri merupakan kontrol perilaku yang berasal dari dalam diri seseorang, dan bukan berasal dari luar diri, dimana keputusan tidak dipengaruhi oleh faktor eksternal.

Teori determinasi diri adalah sebuah teori yang menekankan pentingnya kebebasan individu dalam bertindak sesuai pilihannya, dan juga adanya motivasi instrinsik dalam diri individu, sehingga ketika individu termotivasi secara ekstrinsik dan mengharapkan penghargaan eksternal maka hasil yang diperoleh akan negatif (Vandenbos, 2008).

Teori determinasi diri diperkenalkan oleh Edward Deci dan Ryan Richard tahun 1985, dimana mereka mengusulkan teori tentang manusia memiliki tiga kebutuhan psikologis dasar yaitu otonomi, hubungan, dan kompetensi. Faktorfaktor basic needs yang mempengaruhi determinasi diri adalah (Deci \& Ryan, 2002): (1) Autonomy merupakan kebebasan yang dimiliki individu dalam melakukan sesuatu berdasarkan pilihannya sendiri yang mengacu pada hal yang dirasakan dan bersumber dari dirinya sendiri; (2) Relatedness merupakan hubungan sosial atau relasi sosial individu dalam berinteraksi dengan individu lain dalam satu komunitas serta 
memiliki rasa saling bergantung satu dengan yang lain; (3) Competence merupakan kemampuan individu untuk menunjukkan apa yang dia bisa serta memberikan dampak bagi lingkungan.

Teori determinasi diri ini berfokus pada sifat dasar motivasi, yaitu mengapa berperilaku, dimana asumsi yang mendasarinya adalah bahwa manusia merupakan organisme aktif dan berorientasi pada pertumbuhan yang secara alami cenderung menggabungkan unsurunsur psikis mereka ke dalam suatu perasaan dalam diri dan menggabukan diri mereka ke dalam struktur sosial yang lebih besar.

Teori determinasi diri membuat perbedaan antara motivasi ekstrinsik yang ditetapkan pribadi/ self determined atau otonomik dengan motivasi ekstrinsik yang terkendali atau controlled beserta dampaknya yang berbeda pada kualitas pengalaman belajar. Motivasi ekstrinsik yang terkendali bergantung pada ganjaran atau sanksi serta pada pandangan pribadi tentang apa yang diharapkan dari diri sendiri yang menghasilkan perilaku sebagai tanggapan terhadap tekanan karena perilaku itu dikendalikan dari luar individu. Motivasi ekstrinsik yang otonomik berubah menjadi motivasi intrinsik yang dideterminasikan diri, yang disetujui diri sendiri, merefleksikan diri hingga menarik, menyenangkan dan penting bagi diri sendiri. Motivasi ekstrinsik yang jadi milik sendiri ini memunculkan suatu perilaku.

Teori determinasi diri sebagai kemampuan kontrol perilaku yang berasal dari dalam diri individu yang bukan berasal dari luar diri individu dimana keputusan tidak dipengaruhi oleh faktor eksternal dan kecenderungan individu untuk mencari pengetahuan baru tentang diri sendiri yang nantinya akan diterapkan dalam kegiatan yang berhubungan dengan orang lain.

\section{Metode Penelitian}

$\begin{array}{ccr}\text { Jenis } & \text { penelitian } & \text { ini } \\ \text { menggunakan } & \text { kualitatif } & \text { dengan } \\ \text { pendekatan fenomenologi. } & \text { Adapun }\end{array}$ subjek dalam penelitian ini yaitu Generasi Milenial yang berstatus mahasiswa di Kota Depok. Hal ini dikarenakan kota Depok merupakan salah satu kota yang mendapatkan penghargaan dari TeSCA, yang bertujuan untuk mengukur pemanfaatan Teknologi Informasi dan Komunikasi (TIK) pada perguruan tinggi di Indonesia. Informan penelitian dipilih secara sengaja berdasarkan kriteria yang telah ditentukan sebagai berikut: (1) Milenial kota Depok berumur 18-24 tahun; (2) Mahasiswa Universitas Indonesia atau Universitas Gunadarma karena TeSCA memberikan penghargaan kepada Perguruan Tinggi Universitas Indonesia yang menduduki peringkat ke 2 TeSCA, dan Universitas Gunadarma menduduki peringkat ke 3 TeSCA berdasarkan laman (https://ayokuliah.id/ diakses pada 13 Maret 2020 pukul 16.28 WIB); (3) Mengisi kuesioner pada laman website https://psychcentral.com/quizzes/FO MO-quiz/ untuk mendeteksi sindrom FoMO (Fear of Missing Out); (4) Informan sering menggunakan gadget dalam aktivitas sehari-hari; (5) Aktif dalam menggunakan media sosial; 
Teknik pengumpulan data yang digunakan peneliti antara lain melakukan observasi, melakukan wawancara dengan 6 informan berstatus mahasiswa di Kota Depok, yang mengalami sindrom FoMO pada level Medium FoMO dengan score (23-29) yang tertera pada laman website https://psychcentral.com/quizzes/FO MO-quiz/.

\section{Hasil Penelitian dan Pembahasan}

Penelitian ini membahas mengenai fenomena kecanduan media sosial (FoMO) pada Generasi Milenial, dimana peneliti menggunakan teori yang berkaitan yaitu teori Determinasi Diri untuk mengetahui dampak yang terjadi pada diri Milenial yang mengalami kecanduan media sosial (FoMO) guna menghasilkan penelitian yang konkrit dan akurat.

Aspek penting pada teori determinasi diri menekankan pada pentingnya kebebasan individu dalam bertindak sesuai pilihannya, dan juga adanya motivasi instrinsik dalam diri individu, sehingga ketika individu termotivasi secara ekstrinsik dan mengharapkan penghargaan eksternal maka hasil yang diperoleh akan negatif (Vandenbos, 2008).

Jika dikaitkan dengan perkembangan teknologi dan internet dampak yang ditimbulkan ialah menjadi kecanduan akan media sosial (FoMO) dimana hal ini membawa generasi milenial menjadi memiliki kebutuhan akan media sosial.

Penggunaan media sosial yang berlebihan akan menyebabkan dampak negatif pada diri mereka, seperti adanya rasa kegelisahan pada diri mereka ketika mereka tidak mengakses media sosial, berikut kutipan yang disampaikan oleh NK.

"Yang paling kerasa sih apa ya? Kayak paling nggak tau apa-apa gitu sih, maksudnya kayak ngerasa bodoh gitu loh, kayak misalnya diajak ngobrol terus kita nggak tau kan kita ngerasa paling bodohkan, terus kalo misalnya orang-orang pada ngobrol tentang misalnya tuh kalo misalnya kita nggak tau apa ya? Nggak asik gitu jadinya kita sendiri ngerasa canggung, kalo aku sih ngerasanya kayak gitu ya. Iya sih ngerasa gelisah sama khawatir tuh pasti, dan yang tadi aku bilang aku tuh nggak suka banget kalo misalnya kelihatan bodoh, karena nggak tau suatu informasi gitu, jadi pengennya tuh setiap kali ketemu temen-temen ngobrol aku juga pengen ikutan ngobrolkan." (Wawancara NK, 22 April 2020)

NK mengungkapkan bahwa dirinya merasa menjadi orang bodoh yang tidak tahu informasi apapun jika tidak mengakses media sosial, dan hal itu secara tidak langsung membuat diri NK merasa canggung saat berinteraksi dengan temantemannya. Tidak hanya itu, hal yang senada diungkapkan juga oleh LN dalam kutipannya sebagai berikut:

"Kayak ngerasa jadi manusia terbodoh didunia. Ya iya kesel karena kayak kudet banget masa kayak gitu aja nggak tau, kesel gitu, gimana ya jelasinnya kayak gini misalkan aku chatingan, terus si orang ini temen chattingku ini ngomong sesuatu hal yang aku nggak tau, aku ngerasa ya kayak bego, jadi aku kayak nggak mau nanya "emang itu apa?" nggak mau banget gitu 
jadi menghindari hal-hal yang kayak gitu, makanya kalo misalkan sampe terjadi hal yang kayak gitu kayak yang takut dianggap bodoh "yah nggak update banget sih" gitu." (Wawancara LN, 1 Mei 2020)

LN merasakan hal yang serupa dengan NK, dimana LN merasa kesal pada dirinya sendiri jika dinilai kurang update dengan informasi, dan untuk menghindari hal itu LN berusaha untuk tetap terus update dengan berbagai informasi. Begitupun dengan ungkapan RP dimana dirinya lekas mencari tahu agar tidak tertinggal berita terupdate dimana dalam kutipannya sebagai berikut:

"Langsung buru-buru nyari sih biar nggak ketinggalan update gitu ya, atau nggak nanya ke temen kayak "eh nyarinya dimana tuh?" biar cepet dapet infonya. Perasaannya ya gelisah karena "lah kok belum tau ya?" karena jadinya gua banyak belum tau banyak hal, jadinya gua tuh dalam interaksi sosial yang langsung gitu atau lewat virtual juga jadi kayak merasa kurang bisa inform ke pergaulan lagi gitu, kalo misalnya ada info-info yang gua nggak tau, karenakan kalo misalnya kita berinteraksi sama temen tuh berbincangnya topik tertentu gitu, kalo misalnya kita nggak tau topik itu ya kita nggak bisa bergaul." (Wawancara RP, 6 Mei 2020)

Perasaan gelisah timbul pada diri RP, dimana dalam ungkapan tersebut RP menambahkan bahwa menurutnya dalam interaksi sosial membutuhkan wawasan yang luas agar pada saat berinteraksi dengan siapapun bisa nyambung. Selain itu berbeda halnya jika seseorang yang mengalami FoMO ketertinggalan momen yang berharga, seperti yang diungkapkan oleh JF dalam kutipannya sebagai berikut:

"Kadang ada nyeselnya, kalo gua ketinggalan momen yang berharga itu berarti gua ketinggalan informasinya dong secara nggak langsung, jadinya nyesel, terus kenapa gua nggak tau sih gitu." (Wawancara JF, 28 April 2020)

Menurut JF terkadang dirinya merasa menyesal jika tertinggal momen yang berharga baginya, karena menurutnya jika dirinya ketertinggalan momen yang berharga berarti dirinya juga ketertinggalan informasinya secara tidak lagsung. Hal yang sama dirasakan juga oleh RP dalam kutipannya sebagai berikut:

"Ya pasti kalo ketinggalan momen yang berharga tuh pasti nyesel, tapi yaudah sih, yaudah jadi kayak jadiin pelajaran aja besok-besok kalo misalnya ada hal-hal yang kayak gitu manfaatin waktu, terus usahain maksudnya diusahain ikutlah kalo misalnya emang momen-momen itu bisa berpotensi beharga lagi kedepannya, pokoknya jadiin nyesel kita itu jadi pelajaran buat kedepannya aja gitu, jadi nggak berlarut-larut." (Wawancara RP, 6 Mei 2020)

RP menambahkan dalam ungkapannya dimana jika dirinya tertinggal momen yang berharga, hal yang dilakukannya hanya cukup menjadikan hal tersebut sebagai pelajaran agar tidak terulang kembali dikemudian hari, sama halnya dengan yang diungkapkan juga oleh JF dalam kutipannya sebagai berikut: "Hal apa mungkin untuk kedepannya, untuk next nya 
mungkin gua harus bakal lebih tau lagi tentang temen-temen gua, jadi gua bisa ikut campur." (Wawancara JF, 28 April 2020)

Hal yang dilakukan JF agar tidak ketertinggalan momen ialah dengan cara mencari tahu kegiatan yang dilakukan teman-temannya melalui media sosial, sehingga tanpa disadari hal tersebut mempengaruhi dirinya untuk selalu mengakses media sosial dimana akan menjadi sebuah ketergantungan bagi Milenial yang mengalami kecanduan media sosial (FoMO), seperti yang diungkapkan oleh CM dalam kutipannya sebagai berikut:

"Kalo misalnya buat sama media sosial gitu-gitu yang bikin ketergantungan itu hmm... apa ya? Likes, likes bisa dibilang iya sih, maksudnya udah berapa gitu yang ngelike setelah aku posting, nah tapi itu dulu karena sekarang itu media sosial aku tuh IG ya khususnya itu aku nggak ngeaktifin notif, nggak aktifin kalo misalnya ada yang ngelike, ada yang comment itu aku nggak ngaktifin terus kalo misalnya ada yang ngedm itu aku aktifin notifnya sisanya nggak aku aktifin notifnya, kenapa? Karena awalnya emang aku ngerasa kayak toxic abis sih, maksudnya gimana ya kayak aku tuh ngecekin hp tuh cuma buat ngeliat doang gitu, udah ada yang ngelike belom ya? Siapa aja ya yang ngelike? Terus udah berapa ya yang ngelike? Terus kayak panik sendiri gitu kalo misalnya yang ngelikenya dikit, ya karena aku kan insecureran kan ya jadi aku ngerasa kalo misalnya yang ngelike dikit tuh kayak "ihh kayaknya postingannya nggak penting deh" gitu terus jadi kayak yang mikir "ngapain gua post ya?
Apa hapus aja ya?" gitu jadi panik sendiri gitukan, nah supaya nggak kayak gitu." (Wawancara CM, 23 April 2020)

Hal yang melatarbelakangi CM menjadi ketergantungan dengan media sosial karena adanya fitur like pada media sosial, dimana dirinya pernah merasa toxic sampai-sampai dirinya selalu mengecek handphonenya untuk melihat like pada postingannya di media sosial, selain itu CM juga merasa penasaran seperti halnya "udah ada yang ngelike belom ya? Siapa aja sih yang ngelike? Udah berapa sih yang ngelike?", dimana hal tersebut dapat membuat dirinya merasa panik, dan jika CM mendapatkan like hanya sedikit CM beranggapan seperti halnya "ihh kayaknya postingannya nggak penting deh, ngapain gua post ya? Apa hapus aja ya?" sehingga dirinya menjadi panik sendiri, jadi karena hal tersebut CM memutuskan untuk menonaktifkan notifikasi pada media sosialnya. Selain itu berbeda halnya dengan $\mathrm{CM}$ yang merasa panik jika melihat notifikasi pada media sosialnya, sebaliknya NK merasa senang pada saat melihat notifikasi dimedia sosialnya.

"Sering sih. Hmm apa ya? Kayak lebih ke seneng gitu kalo misalnya ada respon yang mungkin di comment, atau di dm gitu, terus kayak misalnya apa ya? Ngerasa kayak di apresiasi gitu loh kalo misalnya kita nge-upload terus ternyata "ohh ada yang ngelike, ohh ada yang comment" itu pun kalo misalnya commentnya nggak bagus pun aku ngerasa "ohh ada yang respon gitu”, kalo lebih sederhana lagi tuh kayak pas liat postingan temen-temen aku tuh misal kayak mereka jalan-jalan atau bikin sesuatu gitu, seneng sih 
ngeliatnya, kayak mereka-mereka tuh pada produktif gitu, apalagi ngerasain yang udah aku bilang sebelumnya kayak pada mulai usaha gitu, itu seneng sih kadang ngeliatnya." (Wawancara NK, 22 April 2020)

Bagi NK dirinya sangat merasa senang pada saat dirinya melihat notifikasi dimedia sosialnya baik berupa comment, direct message, like. NK merasa postingannya diapresiasi oleh teman-teman dimedia sosial yang merespon postingannya. Selain itu NK juga merasa senang saat melihat postinn temannya yang sedang melakukan kegiatan yang produktif.

Dalam mengakses media sosial tidak hanya menimbulkan ketergantungan tetapi juga memberikan manfaat bagi Milenial yang mengalami kecanduan media sosial (FoMO), seperti yang dikatakan oleh CM dalam kutipannya sebagai berikut:

"Jelas ada dong, kan dimedia sosial itu tergantungkan, manfaat yang didapat itu tergantung apa yang diakses, kalo misalkan cuman yang dikepoin itu cuman kayak IG nya artis-artis ya apa gitu yang mau didapet, tapi kalo misalnya yang diakses itu kayak berhubungan sama hobi yang kita suka terus juga berhubungan sama misalnya kan banyak juga tuh di IG kan DIY DIY gitu, itu jadi banyak manfaatnya, jadi lebih paling nggak ya ada niatanlah buat jadi produktif selama dirumah, selama nggak ada kegiatan ini gitu, kalo hal lainnya apa ya manfaat lainnya sih jadi tau kabar temen-temen, tapi sebenernya itu juga nggak terlalu penting sih, karenakan yang dimedia sosial itu juga bukan temen yang deket-deket amat gitu paling ya temen yang deket-deket bangetkan ya adanya di kayak Line, di Whatsapp gitukan media sosialnya, nggak yang kayak media general kayak IG gitu, jadi ya paling manfaatnya itu sih, jadi banyak tau informasi, terus juga life long learning berhubungan sama literasi informasi itu sendiri jadi kayak kita selalu terupgrade setiap harinya dengan informasiinformasi yang baru, terus pengetahuan yang baru, jadi lebih banyak tau, terus juga jadi apa ya? jadi lebih kemotivasi kayak misalnya kepo-kepoin vlog-vlog artis-artis yang bukan artis, public figure, public figure, yang apa namanya tuh kayak Maudy Ayunda gitukan, inspirasiinspirasi muda gitu, itu banyak banget tuh manfaatnya kalo menurut aku, gitu sih jadi ya tergantung apa yang diakses ya apa yang didapat gitu, tapi yang jelas pasti ada manfaatnya. Kalo dari aku sendiri manfaatnya karena biasanyakan aku jarangjarang cari info tentang orangkan, biasanya kayak tentang topik-topik tertentu, manfaatnya lebih ini sih, lebih apa? Kan kalo dimedia sosial tuh pendapat orangkan, jadi tuh kalo misalnya ngeceknya dari media sosial tuh topik-topik yang aku pengen tau itu jadi kayak lebih banyak insidenya gitu loh, kayak yang aku dapet tuh nggak cuman sesuai teori tapi sesuai apa yang udah dirasain sama orang itu gitu. Jadi kayak lebih apa ya? Lebih ngena gitu loh kalo misalnya cari sesuatu yang berhubungan sama info-info gitu dibanding sama yang kayak website-website gitukan kadang kayak resmi bangetkan gitu sih paling." (Wawancara CM, 23 April 2020) 
CM mengatakan bahwa manfaat dari media sosial itu tergantung dengan hal seperti apa yang diaksesnya, CM merasa bahwa dirinya selalu ter upgrade dengan informasi-informasi yang baru setiap harinya di media sosial, dimana hal tersebut membuat $\mathrm{CM}$ menjadi lebih banyak tahu informasi dan memiliki wawasan yang membuat dirinya menjadi termotivasi. Seperti halnya dalam menggunakan media sosial yang digunakan sebagai media untuk mengasah hobi yang dimilikinya untuk menjadi lebih produktif. Hal yang sama diungkapkan juga oleh JF dalam kutipannya sebagai berikut:

"Ada pastinya, pastinya ada yang pertamakan namanya informasi pasti ngasih pengetahuan, itu yang pertama, jadi kadang ada pengetahuan baru yang kedua kita juga kita nggak ketinggalan berita misalnya ngobrol sama temen-temen, terus yang ketiga juga kita untuk saya sendiri jadi punya wawasan luas dalam artian kita mau ngobrol sama siapapun masuk dan kita tau dasarnya gitu sih." (Wawancara JF, 28 April 2020)

Menurut JF dalam mengakses media sosial terdapat banyak manfaat seperti halnya menambah pengetahuan dan tidak tertinggal berita sehingga hal tersebut membuat dirinya memiliki wawasan yang luas agar pada saat berinteraksi dengan teman-temannya dirinya dapat mengarahkan topik pembicaraan.

Seperti halnya yang telah diungkapkan oleh beberapa informan Milenial yang mengalami kecanduan media sosial (FoMO) dimana jika mereka ketertinggalan informasi mereka merasakan khawatir dan gelisah karena dirinya terlihat bodoh dimana terkesan kudet (kurang update), bahkan mereka merasa kesal pada diri mereka sendiri. Bagi mereka dalam interaksi sosial membutuhkan wawasan yang luas agar pada saat berinteraksi dengan siapapun bisa saling mengerti dan memahami.

Pada saat para informan merasa kehilangan moment yang berharga maka di dalam dirinya akan timbul penyesalan. Hal ini karena bagi para informan, secara tidak langsung diri mereka juga ketertinggalan informasinya sehingga mereka menjadikan hal tersebut sebagai pelajaran agar tidak terulang kembali dikemudian hari dengan selalu mencari tahu kegiatan yang dilakukan teman-temannya melalui media sosial. Tanpa disadari hal tersebut membuat diri mereka menjadi merasa toxic karena selalu mengecek handphone nya dan membuat diri mereka menjadi ketergantungan dengan media sosial.

Para informan merasa senang saat melihat postingan temantemannya yang sedang melakukan kegiatan produktif, bahkan mereka juga merasa senang pada saat mendapatkan notifikasi dimedia sosialnya seperti comment, direct message, like, dimana mereka merasa bahwa teman-teman dimedia sosial yang merespon postingannya memberikan mereka apresiasi. Namun dengan adanya fitur tersebut membuat diri mereka menjadi selalu penasaran sehingga menimbulkan rasa panik, seperti halnya ketika mereka memposting sesuatu dimedia sosial tetapi like atau comment yang didapatkannya tidak sesuai dengan yang diharapkannya sehingga mereka sering beranggapan negatif 
sehingga mereka memutuskan untuk menonaktifkan notifikasi pada media sosialnya. Bagi para informan media sosial juga memberikan manfaat bagi diri mereka seperti mereka yang mengaku ketergantungan dengan media sosial menjadikan dirinya selalu terupgrade dengan informasiinformasi terbaru setiap harinya, sehingga dirinya menjadi lebih banyak tahu informasi dan memiliki wawasan yang membuat dirinya menjadi termotivasi. Tidak hanya itu mereka juga menggunakan media sosial untuk mengasah hobi untuk menjadi lebih produktif. Dimana jika dirinya terlalu asyik mengakses media sosial akan lupa waktu, seperti yang diungkapkan oleh CM dalam kutipannya sebagai berikut:

"Pasti lupa waktu, misalnya keasyikkan kepo informasi tertentu atau keasyikan searching tentang produk tertentu sampe lupa waktu gitu loh, tau-tau udah jam berapa, terus misalnya harusnya tadinya udah niat pas pagi harinya mau kayak misalnya "ah gua harus produktif nih hari ini mau ini, mau itu, mau ini, mau itu", tapi karena ternyata keasyikan main handphone, keasyikan buka medsos ya jadinya gagal deh, ditunda lagi besok, besok kayak gitu lagi ditunda lagi, kayak gitu aja terus." (Wawancara CM, 23 April 2020)

CM mengungkapkan bahwa saat dirinya sedang asyik dengan media sosialnya membuat dirinya menjadi lupa waktu, seperti halnya saat CM ingin melakukan hal yang produktif tetapi dirinya keasyikan buka media sosial sehingga niatnya untuk melakukan hal yang produktif menjadi gagal. Hal yang sama diungkapkan juga oleh NK dalam kutipannya sebagai berikut:
"Sering sih lalai sama kewajiban ya, kayak misalnya nunda tugas, nunda tidur, nunda makan. Itu tuh sebenernya juga bahaya buat diri sendiri gitu loh." (Wawancara NK, 22 April 2020)

Hal yang sama juga terjadi pada NK, dimana mengakibatkan dirinya menjadi lalai dengan kewajibannya, dimana menurut NK hal itu dapat membahayakan dirinya sendiri. Dimana hal ini menimbulkan perasaan menyesal seperti yang diungkapkan oleh RP dalam kutipannya sebagai berikut:

"Nah ini kadang suka nyesel sih kalo misal udah lama nyesel, langsung matiin hp biasanya tuh. $\mathrm{Ya}$ ini ngabisin waktu, kadang jadi lupa ngerjain beberapa hal yang harus saya lakuin juga jadinya ditunda gitu." (Wawancara RP, 6 Mei 2020)

RP mengatakan bahwa dirinya suka merasa menyesal saat merasa asyik dengan media sosialnya, karena menurutnya hal yang dilakukannya itu hanya menghabiskan waktu saja, sehingga pekerjaan yang ingin dilakukannya menjadi tertunda. Berbeda halnya dengan yang diungkapkan oleh LN dalam kutipannya sebagai berikut:

"Menurut aku jadinya kayak kecanduan sih, kecanduan parah yang kalo nggak main media sosial kayak nggak bisa, terus kayak lupa waktu, jadi males ngapa-ngapain maunya main $\mathrm{hp}$ aja, main media sosial terus, bahkan kadang sampe lupa gitu kalo ternyata kita punya kehidupan di dunia nyata." (Wawancara LN, 1 Mei 2020)

Menurut LN hal yang terjadi jika dirinya terlalu asyik dengan media sosial ialah menjadi candu, sehingga dirinya sering lupa waktu 
dan selalu ingin bermalas-malasan sambil membuka media sosialnya, bahkan dirinya sendiri sampai lupa kalau ternyata punya kehidupan didunia nyata. Berbeda halnya yang terjadi pada MU dimana dirinya menjadi susah tidur jika terlalu asyik membuka media sosial.

"Yang terjadi susah tidur itu penting banget itu yang utama, karena saat main hp ehh tiba-tiba nggak liat waktu, tiba-tiba udah pagi, kan padahal udah capek banget tapi matanya masih terang benderang ngeliat layar handphone." (Wawancara MU, 9 Mei 2020)

MU menambahkan dalam kutipannya bahwa dirinya merasa susah tidur saat terlalu asyik membuka media sosialnya, sehingga jam tidur MU menjadi tidak teratur. Lain halnya jika Milenial yang mengalami kecanduan media sosial (FoMO) tidak dapat mengakses media sosialnya dalam sehari, seperti halnya yang diungkapkan oleh NK dalam kutipannya sebagai berikut:

"Pasti ngerasa gabut sih, terus juga biasanya tuh sampe ngerasa ngerasa stress gitu loh, kalo misalnya karenakan kuota jadi kebutuhan primer juga tuh, nah kalo misalnya aku lagi dikosan terus kuotaku habis tapi belom bisa beli kuota lagi tuh pasti aku bakal stay di kampus tuh sampe malem banget buat cari wifi, terus kalo selain itu kalo aku lagi di kamar jadi kayak kosanku tuh suka tiba-tiba susah sinyal gitukan, pasti aku bakal keluar kosan kayak jalan kemanapun buat nyari sinyal gitu." (Wawancara NK, 22 April 2020)

NK merasa stress jika dirinya tidak dapat mengakses media sosialnya, karena baginya kuota internet merupakan kebutuhan primer dimana didalam kehidupan sehari-harinya dirinya membutuhkan kuota internet atau wifi untuk tetap selalu terkoneksi dengan media sosialnya. Senada halnya yang diungkapkan oleh LN dalam kutipannya sebagai berikut:

"Nggak nyaman, paket mati bentar aja nggak bisa, harus langsung, mau mati harus langsung isi nggak bisa mati. Pasti bakal marah-marah, kayak rasanya kesel aja, nggak tau harus ngapain, terus kayak marah sih intinya kayak kesel, kesel banget kayak hampa. Ya mencari cara biar itu cepet berakhir, kayak apa nih, minta tethering atau beli kuota segera atau minjem $h p$ orang gitu. (Wawancara LN, 1 Mei 2020)

LN mengatakan bahwa dirinya merasa tidak nyaman jika tidak dapat mengakses media sosialnya dalam sehari, sehingga LN langsung segera mengisi ulang paketnya agar terus terhubung dengan media sosialnya, atau mencari cara seperti misalnya meminta tethering atau meminjam handphone temannya. Hal yang sama juga terjadi pada RP yang diungkapkannya dalam kutipan sebagai berikut:

"Ya nggak bisa sih, sampe sekarang soalnya belom pernah sehari tuh tanpa media sosial, jadi kalo misalnya hal itu terjadi pastinya gelisah, kedua ya berusaha ketemu maksudnya secara langsung gitu ya berinteraksi gitu diluar kondisi yang sekarang ya gitu kalo misalnya media sosial nggak bisa, bahkan kemaren media sosial gua disuspend gitu kan sama Twitter, teruskan gua butuh waktu tuh buat ngebalikin lagi terus gua langsung bikin Twitter baru biar 
nggak ketinggalan info."

(Wawancara RP, 6 Mei 2020)

Bagi RP dirinya belum pernah sehari tanpa media sosial karena jika hal itu terjadi dirinya akan merasa gelisah, dan bahkan pada saat media sosialnya disuspend, RP segera membuat akun baru agar tidak ketinggalan informasi apapun. Begitu pun yang terjadi pada MU yang diungkapkannya melalui kutipannya sebagai berikut:

"Hampa, kayak nggak mungkin sih, kayak pasti bakal banget mengakses media sosial, jadi bener-bener walaupun pengen me time sama diri sendiri tetep aja harus ngakses media sosial, karenakan aku bukan tipe orang yang bener-bener introvert yang bener-bener pengen sendiri banget, jadi nggak mengakses media sosial tuh nggak mungkin." (Wawancara MU, 9 Mei 2020)

MU juga merasa hampa, karena menurutnya untuk tidak mengakses media sosial dalam sehari merupakan hal yang tidak mungkin bagi dirinya, dimana saat dalam keadaan sendiri pun MU selalu mengakses media sosialnya. Berbeda halnya dengan yang diungkapkan oleh CM dalam kutipannya sebagai berikut:

"Kalo gimananya pasti bakal bangga banget sih, kenapa? Karena yang tadinya ngerasa bisa dibilang addict sama kecanduan media sosial terus dalam sehari bisa nggak buka gitu, kayak suatu kebanggaan gitu nggak sih? Kalo aku sih ngerasanya kayak gitu dan sejujurnya aku baru abis ngedeacctived akun pertama di $I G$ dan kayak pas ngelakuin itu nggak sedih, nggak panik, nggak apa, tapi justru malah ngerasa bangga gitu loh kayak "anjir bisa nih gua!" gitukan, dan sejujurnya ngerasa lebih tenang malah pas nggak ngakses itu dan jadi nyadar gitu loh kayak ada disatu titik itu ngerasa kayak "ya sebenernya lu nggak tau kabar mereka juga gapapa gitu, mereka nggak tau kabar lu juga gapapa gitu”, terus kayak ngerasa kalo lu happy lu nggak ngeshare ke orang ya lu juga gapapa gitu, nggak perlu harus selalu disharekan kayak kalo pun lu sedih yaudah gitu rasain aja sendiri jadi lebih enak gitu sih sejujurnya." (Wawancara CM, 23 April 2020)

Bagi CM dirinya merasa bangga jika mampu untuk tidak mengakses media sosialnya dalam sehari, karena menurutnya dirinya sudah terlalu kecanduan dengan media sosial sehingga setiap saat CM selalu mengakses media sosialnya. Tetapi setelah dirinya mencoba untuk menonaktifkan media sosialnya, justru CM merasa menjadi lebih tenang dan menjadi sadar seperti halnya tidak semua hal harus upload ke media sosial dan tidak semua hal harus diberi tahu orang lain, karena hal tersebut cukup dengan merasakan sendiri tanpa orang lain harus tahu.

Seperti halnya yang telah diungkapkan oleh beberapa informan Milenial yang mengalami kecanduan media sosial (FoMO) dimana jika mereka terlalu asyik mengakses media sosial mereka menjadi kecanduan sehingga lupa waktu yang mengakibatkan dirinya menjadi lalai dengan kewajibannya dan selalu ingin bermalas-malasan sambil membuka media sosial mereka, bahkan mereka sendiri sampai lupa kalau ternyata punya kehidupan didunia nyata, dimana bagi mereka 
hal itu dapat membahayakan diri mereka sendiri dan menimbulkan perasaan menyesal karena menurut mereka hal yang dilakukannya itu hanya menghabiskan waktu saja, sehingga pekerjaan yang ingin dilakukannya menjadi tertunda. Tidak hanya itu saja mereka juga menjadi susah tidur yang menyebabkan jam tidur menjadi tidak teratur.

Lain halnya jika Milenial yang mengalami kecanduan media sosial (FoMO) tidak dapat mengakses media sosialnya dalam sehari, mereka akan merasa stres dan gelisah karena bagi mereka kuota internet merupakan kebutuhan primer dimana didalam kehidupan sehari-harinya mereka membutuhkan kuota internet atau wifi untuk tetap selalu terkoneksi dengan media sosialnya. atau mencari cara seperti misalnya meminjam handphone temannya untuk mengakses media sosial, karena bagi mereka untuk tidak mengakses media sosial dalam sehari merupakan hal yang tidak mungkin.

Berbeda dengan salah satu dari informan yang mengalami kecanduan media sosial (FoMO) mengungkapkan bahwa dirinya merasa bangga jika mampu untuk tidak mengakses media sosialnya dalam sehari, karena menurutnya dirinya sudah terlalu kecanduan dengan media sosial sehingga setiap saat dirinya selalu mengakses media sosial, sehingga dirinya mencoba untuk menonaktifkan media sosialnya, dan ternyata dengan melakukan hal itu membuat dirinya menjadi lebih tenang dan menjadi sadar karena tidak semua hal harus upload ke media sosial, karena tidak semua hal harus diberi tahu orang lain cukup dengan merasakan sendiri tanpa orang lain harus tahu. Begitupun dengan pengaruh media sosial terhadap diri Milenial yang mengalami kecanduan media sosial (FoMO) dimana terdapat dampak positif dan negatif bagi diri mereka, seperti yang diungkapkan oleh CM dalam kutipannya sebagai berikut:

"Pengaruhnya banyak, positif atau negatif sebenernya nggak bisa bilang secara gamblang gitu tapi emang banyaknya dampak negatifnya sejauh ini, kenapa? Karena ngerasa jadi selalu, jadi gimana ya? Ngerasa selalu terpacu dalam artian kayak sejujurnya tuh nggak mau kalah gitu loh, misalnya kayak meskipun nggak diwujudin ya, kayak misalnya ngeliat ada nih orang ngepost gitu terus kayak "ih dia kesini nih" terus pastikan otomatis gitukan dalam hati kayak "ahh gua juga bisa" misalnya kayak "ihh pengen juga deh" atau kayak apa ya? Jadi kayak sering ngehujat orang gitu loh meskipun itu cuma didalam diri sendiri, tapi ya sebenernya itu toxic juga sih kalo kelamaan kayak jadinya tuh susah ngeliat sisi positif dari suatu hal yang seharusnya itu hal yang positif tapi karena pikirannya udah terlanjur negatif sama orang itu atau gimana jadinya ya media sosialnya itu jadi sarana buat aku pribadi makin berfikir negatif gitu, tapi ya sebenernya dari media sosial dari hal-hal negatifnya media sosial itu sendiri justru aku malah ngedapetin banyak hal-hal yang positif kayak misalnya kayak itu tadikan aku ngerasa aku jadi gampang iri, atau kayak misalnya ngerasa, ngerasa gimana ya? Ngerasa kayak minder atau ngerasa tersaingi atau apa, nah 
dari situ aku jadi bisa dapet dampak positifnya kayak misalnya ya yaudah gitu setiap kehidupan orangkan pasti ada up and down nya gitukan, jadi pas aku ngerasa aku iri sama orang lain ya aku jadi ngerasa aku harus lebih banyak bersyukur gitu, terus jadi kayak ngebalikin ke diri sendiri gitu loh kayak "kenapa sih gua harus iri gitu? Apa yang harus diiriin gitu?" sementara gua udah punya seтua ini gitu, gua udah punya kehidupan kayak gini gitu misalnya jadi ya sebenernya sisi positif sama sisi negatifnya itu kayak koin gitu loh si media sosialnya itu menurut aku, jadi secara berdampingan aku ngerasain sisi negatif tapi aku juga ngerasain sisi positifnya, jadi kalo dibilang dampaknya lebih banyak itu yang mana negatif atau positif seimbang sih, seimbang, iya kayak gitu sih." (Wawancara CM, 23 April 2020)

Menurut CM pengaruh media sosial terhadap dirinya seimbang, dimana CM merasa bahwa sisi negatif dan sisi positif saling berdampingan, karena pada saat dirinya merasa iri, merasa minder atau merasa tersaingi dengan postingan orang lain dimedia sosial, hal tersebut menimbulkan dampak positif bagi dirinya seperti halnya CM menjadi lebih bersyukur dengan apa yang dirinya punya. Seperti halnya dengan ungkapan yang disampaikan oleh LN dimana pengaruh media sosial terhadap dirinya terdapat sisi negative dan positifnya.

"Hmm dampak buat diri aku hmm, kayak aku sedikit kecanduan media sosial sih karena apa-apa diupload, dampak negatifnya itu, kalo dampak positifnya sih yaitu bisa dapet banyak informasi dari media sosial dan dapat banyak temen juga, tapi kalo dipikir-pikir lebih ke dampak positif sih karena kecanduannya nggak sampe yang bikin ngelupain segalanya gitu." (Wawancara LN, 1 Mei 2020)

LN mengungkapkan dalam kutipannya bahwa pengaruh media sosial terhadap dirinya ialah menjadi kecanduan dengan media sosial, dimana dirinya selalu mengupload hal apapun pada media sosialnya, dan hal itu membuat dirinya menjadi mempunyai banyak teman dimedia sosialnya. Selain itu dampak positif yang didapatnya seperti mendapatkan banyak informasi dari media sosial. Begitupun hal yang diungkapkan oleh JF dalam kutipannya sebagai berikut:

"Positif, hampir 80\% nya positif, dampak positifnya pastinya kita nambah pengetahuan terus nambah ilmu, wawasan juga lebih luas, terus banyak sih jadi kita juga asyik kalo ngobrol sama lingkungan atau temen-temen kita lagi ngebahas apa jadi kita tau dasar-dasarnya, positifnya lebih ngarah kesitu sih. Negatifnya kadang kalo secara gua personal karena gua udah bisa memilah berita yang baik sama yang benar, berita yang salah sama yang benar itu jadinya jadi kita tau kayak berita-berita hoax itu kan lagi banyak banget kayak gitu, nah itu kadang bisa jadi boomerang buat kita atau bisa jadi hal negatif buat kita kalo kita terima mentah-mentah." (Wawancara JF, 28 April 2020)

Bagi JF pengaruh media sosial terhadap dirinya $80 \%$ positif, dimana dampak positif yang didapat dirinya seperi menambah pengetahuan sehingga memiliki wawasan yang lebih luas, selain itu saat berinteraksi 
dengan teman pun menjadi lebih asyik dimana dirinya tahu dengan topik yang sedang dibahas, tetapi hal tersebut bisa menjadi boomerang bagi dirinya jika informasi yang didaptnya diterima mentah-mentah tanpa mencari tahu terlebih dahulu.

Berdasarkan ungkapan yang telah disampaikan oleh beberapa informan Milenial yang mengalami kecanduan media sosial (FoMO) dimana pengaruh media sosial terhadap diri mereka seimbang, dimana sisi negatif dan sisi positif saling berdampingan, seperti halnya pada saat dirinya merasa iri, merasa minder atau merasa tersaingi dengan postingan orang lain dimedia sosial, hal tersebut justru menimbulkan dampak positif bagi diri mereka dimana menjadi lebih bersyukur dengan apa yang dirinya punya. Tidak hanya itu bahkan pada saat menjadi kecanduan dengan media sosial, justru hal itu membuat dirinya menjadi mempunyai banyak teman dimedia sosial.

Dapat disimpulkan bahwa keenam informan Milenial yang mengalami kecanduan media sosial (FoMO) dapat dilihat dampak yang timbul pada diri mereka dimana jika mereka ketertinggalan informasi mereka merasakan khawatir, begitupun pada saat mereka ketertinggalan moment dimana dirinya merasa menyesal, karena secara tidak langsung diri mereka ketertinggalan dengan informasinya. Intensitas yang tinggi dalam mengakses media sosial menyebabkan para informan menjadi toxic dengan melihat postingan teman-temannya di media sosial yang menyebabkan dirinya ketergantungan dengan media sosial.
Media sosial juga memberikan manfaat bagi diri mereka seperti mereka yang mengaku ketergantungan dengan media sosial menjadikan dirinya selalu terupgrade dengan informasi-informasi terbaru setiap harinya, sehingga dirinya menjadi lebih banyak tahu informasi dan memiliki wawasan yang membuat dirinya menjadi termotivasi untuk melakukan suatu hal dimana untuk mengasah hobi mereka menjadi lebih produktif. Hal tersebut menyebabkan para informan menjadi kecanduan sehingga lupa waktu yang mengakibatkan dirinya menjadi lalai dengan kewajibannya dan selalu ingin bermalas-malasan sambil membuka media sosial mereka, bahkan mereka sendiri sampai lupa kalau ternyata punya kehidupan didunia nyata, tidak hanya itu mereka juga menjadi susah tidur.

Beda halnya jika mereka tidak dapat mengakses media sosialnya dalam sehari, dimana mereka akan merasa stres dan gelisah karena bagi mereka untuk tidak mengakses media sosial dalam sehari merupakan hal yang tidak mungkin. dimana bagi mereka mengakses media sosial merupakan kebutuhan, bahkan mereka sampai meminjam handphone temannya hanya untuk mengakses media sosial. Tetapi salah satu dari mereka sudah mencoba untuk menonaktifkan media sosialnya, dan ternyata dengan melakukan hal itu membuat dirinya menjadi lebih tenang dan menjadi sadar karena tidak semua hal harus upload ke media sosial, karena tidak semua hal harus diberi tahu orang lain cukup dengan merasakan sendiri tanpa orang lain harus tahu. 
Sebagaimana Milenial yang mengalami kecanduan media sosial (FoMO) selalu aktif pada media sosial mereka, dimana pengaruh media sosial terhadap diri mereka memiliki sisi negatif dan sisi positif yang saling berdampingan, seperti halnya pada saat dirinya merasa iri, merasa minder atau merasa tersaingi dengan postingan orang lain dimedia sosial, hal tersebut justru menimbulkan dampak positif bagi diri mereka dimana menjadi lebih bersyukur dengan apa yang dirinya punya.

Para informan yang mengaku ketergantungan dengan media sosial menjadikan dirinya selalu terupgrade dengan informasi-informasi terbaru setiap harinya, sehingga dirinya menjadi lebih banyak tahu informasi dan memiliki wawasan yang membuat dirinya menjadi termotivasi untuk melakukan suatu hal dimana untuk mengasah hobi mereka menjadi lebih produktif.

Aspek penting dari teori determinasi diri yang diperkenalkan oleh Edward Deci dan Ryan Richard pada tahun 1985, dimana terdapat tiga kebutuhan psikologis dasar yaitu otonomi (autonomy), hubungan (relatedness), dan kompetensi (competence) yang dapat mengulas dampak yang terjadi pada Milenial yang satu dari informan Milenial yang mengalami kecanduan media sosial (FoMO).

Sebagaimana faktor yang mempengaruhi informan Milenial yang mengalami kecanduan media sosial (FoMO) dalam faktor otonomi (autonomy), dimana dengan seringnya mereka mengakses media sosial untuk melihat postingan teman-teman mereka dapat membuat diri mereka menjadi toxic, sehingga hal itu membuat diri mereka menjadi ketergantungan dengan media sosial. Pada faktor hubungan (relatedness), dimana dengan adanya hubungan emosional yang terjalin para informan Milenial yang mengalami kecanduan media sosial (FoMO) sering kali memperhatikan postingan teman-temannya dimedia sosial, seperti mengenai kegiatan yang sedang dilakukan oleh temanteman mereka, dimana bagi mereka itu merupakan hal yang seru sehingga diri mereka tertarik untuk mencari tahu kegiatan yang dilakukan oleh teman-temannya, melihat perkembangan temantemannya hingga membandingbandingkan dirinya dengan temantemannya dimedia sosial.

Pada faktor kompetensi (competence), dimana mereka yang merasa kecanduan akan media sosial akan merasa stres dan gelisah saat mereka untuk tidak mengakses media sosialnya, dimana bagi mereka mengakses media sosial merupakan kebutuhan, bahkan mereka sampai meminjam handphone temannya hanya untuk mengakses media sosial. Adapun salah satu dari informan Milenial yang mengalami kecanduan media sosial (FoMO) mencoba untuk menonaktifkan media sosialnya, dimana dengan melakukan hal itu membuat dirinya menjadi lebih tenang dan menjadi sadar karena tidak semua hal harus upload ke media sosial, karena tidak semua hal harus diberi tahu orang lain cukup dengan merasakan sendiri tanpa orang lain harus mengetahuinya 


\section{Simpulan}

Berdasarkan hasil penelitian dapat disimpulkan bahwa Sindrom FoMO (Fear of Missing Out) dianggap sebagai dampak dari perkembangan teknologi dan internet, sehingga sindrom FoMO (Fear of Missing Out) berkaitan erat dengan kecanduan akan media sosial dimana mereka selalu berusaha untuk terus tetap up to date dengan informasi pada media sosial, dimana terdapat dampak positif dan negatif diantaranya:

1. Milenial yang mengalami kecanduan media sosial (FoMO), menjadi lebih bersyukur dengan apa yang dirinya punya, dan bahkan beberapa dari mereka memiliki banyak teman dimedia sosial.

2. Seringnya mengakses media sosial membuat diri mereka menjadi toxic, dimana hal tersebut juga memberikan manfaat yang positif seperti selalu terupgrade dengan informasi-informasi terbaru setiap harinya.

3. Kecanduan bermedia sosial mengakibatkan dirinya menjadi lalai dengan kewajibannya dan selalu ingin bermalas-malasan.

\section{Daftar Pustaka}

Artikel Jurnal :

Abel, J. P. (2016). Social Media and the Fear of Missing Out. Scale Development and Assessment. Journal of Business \& Economics Research - First Quarter, 14 (1): 47-65.

Anggraini, Laras. (2014). Fenomena FoMO (Fear of Missing Out) sebagai Salah Satu Bentuk Motivasi Konsumen Millennial. (Makalah Non Seminar). Depok: Fakultas Ilmu Sosial dan Ilmu Politik Universitas Indonesia.

Avi Assor, Guy Roth dan Edward L. Deci. (2004). The Emotional Costs of Parents' Conditional Regard: A Self-Determination Theory Analysis. Journal of Personality.

Carolina, Monica. \& Gayes Mahestu. (2020). Prilaku Komunikasi Remaja dengan Kecenderungan FoMO. Jurnal Riset Komunikasi, Vol.11 No.1, hlm. 69-92.

Christina, Riska,. Muhammad Salis Yuniardi, \& Adhyatman Prabowo. 2019. Hubungan Tingkat Neurotisme dengan Fear of Missing Out (FoMO) pada Remaja Pengguna Aktif Media Sosial. Indigenous: Jurnal Ilmiah Psikologi, vol.4 No.2, hlm. 105-117.

Dossey, L. 2014. FOMO, digital dementia, and our dangerous experiment. Exploreration, 10(2):69-73.

Eijnden, R. J. J. M. V. D., Lemmens, J. S., \& Valkenburg, P. M. (2016). The media sosial disorder scale. Computers in Human Behavior. 61, 478-487. doi: 10.1016/j.chb.2016.03.038

Martha, dkk. 2009. Korelasi Harga Diri Ditinjau dari Gaya Hidup Hedonis pada Mahasiswa 
Universitas Diponegoro. Jurnal Psikologi Universitas Diponegoro.

Maysitoh, Ifdil, \& Zadrian Ardi. 2020. Tingkat Kecenderungan FoMO (Fear of Missing Out) pada Generasi Millenial. Journal of counseling, Education and Society, vol.1 No.1, pp. 1-4.

Muller, dkk. 2006. Personality, motives and learning environment as predictors of self-determined learning motivation. Review of Psychology. Vol. 13. No.2.

Przybylski, A. K., Murayama, K., DeHaan, C. R. \& Gladwell, V. 2013. Motivational, emotional and behavioral correlates of fear of missing out. Journal Homepage: Computer in Human Behavior, 29, 18411848.

Putri, Lisya Septiani, Dadang Hikmah Purnama, \& Abdullah Idi. 2019. Gaya Hidup Mahasiswa pengidap Fear of Missing Out di Kota Palembang. Jurnal Masyarakat dan Budaya, vol.21 No.2, hlm. 129-148.

Song, X., Zhang, X., Zhao, Y., \& Song, S. (2017). Fearing of missing out (FoMO) in mobile social media environment: conceptual development and measurement scale. iConference 2017 Proceedings, 733-738. doi: 10.9776/17330

Buku :

Deci, E. D., \& Ryan,R. M. 2002. Handbook of SelfDetermination Research. New York: University of Rochester Press.

Kotler, Philip. 2002. Manajemen Pemasaran. Jilid 1. Edisi Milenium. Jakarta: Prehallindo. Vandenbos. 2008. Study of Self Determination in general. American: Public Onways.

Internet :

APJII. 2018. Penetrasi \& Profil Prilaku Pengguna Internet Indonesia. https://apjii.or.id/survei2018 (diakses pada 11 Oktober 2019).

Ayokuliah. 2020. Ranking Universitas. https://ayokuliah.id (diakses pada 13 Maret 2020).

Social. W.A., Hootsuite. 2020. Digital 2020: Indonesia. https://datareportal.com/reports /digital-2020-indonesia (diakses pada 13 Maret 2020). 